\title{
MARKERS OF INCREASED RISK OF DEATH IN POLYTRAUMA PATIENTS WITH ASSOCIATED CHEST TRAUMA
}

\section{Cristina TASE GHINGULEAC ${ }^{1 凶}$, Rodica TUDORAN ${ }^{1}$, Sergiu CHIRILA ${ }^{2}$, Leonard GURGAS ${ }^{2}$, lleana ION ${ }^{2}$, Catalina POPOVICI ${ }^{3}$}

${ }^{1}$ County Clinical Emergency Hospital of Constanta, Romania

${ }^{2}$ Faculty of Medicine, University 'Ovidius" of Constanta, Romania

${ }^{3}$ Faculty of Medicine, University of Medicine and Pharmacy „Gr. T. Popa“, Iasi, Romania

Received 13 July 2018, Accepted 22 Aug 2018

https://doi.org/10.31688/ABMU.2018.53.3.14

\begin{abstract}
Introduction. Polytrauma patients represent one of the most difficult pathology. Therefore, developing methods of assessing the risk of death in these patients is a continuous challenge for physicians.

The aim of the study was to evaluate the levels of creatine kinase isoenzyme MB (CK-MB) and troponin, as markers of increased risk of death in the first 24 hours after admission, in polytrauma patients with associated chest trauma.

Material and methods. The study included 33 polytrauma patients treated in the Emergency Department of the County Clinical Emergency Hospital Constanta, Romania, between 2014-2017. In all these patients, clinical evaluation and paraclinical investigations have been performed, including measurements of CK-MB levels.

The results of the study suggest that CK-MB does not offer additional information for the risk of death in these patients, while in the case of troponin, higher values were observed in patients that didn't survive after 24 hours.
\end{abstract}

\section{Résumé}

Paramètres enzymatiques à l'admission et risque de décès chez les patients polytraumatisés présentant un traumatisme thoracique associé

Introduction. Les patients polytraumatisés représentent l'une des conditions médicales les plus difficiles. Développer des méthodes pour évaluer le risque de décès chez ces patients est un effort continu pour le domaine médical.

Le but de l'étude est d'évaluer la créatine kinase isoenzyme MB (CK-MB) et la troponine en tant que marqueurs du risque accru de décès dans les 24 heures suivant l'admission chez des patients polytraumatisés présentant un traumatisme thoracique associé.

Méthodes. L'étude a été menée sur 33 patients traités dans le service des urgences de l'Hôpital Clinique d'Urgence du Département de Constanta, entre 2014 et 2017

Les résultats de l'étude suggèrent que CK-MB n'offre pas d'informations supplémentaires liées au risque de décès chez ces patients, tandis que dans le cas de la troponine, des valeurs plus élevées ont été observées 
Conclusions. The results of our study suggest that troponin values may be useful in identifying the increased risk of death in polytrauma patients.

Keywords: creatine kinase-MB, troponin, polytrauma, thoracic trauma.

\section{INTRODUCTION}

One of the most challenging emergency is polytrauma, that is an important cause of mortality and morbidity ${ }^{1}$. Objective methods that allow a fast evaluation of the patients' outcome are crucial in the first hours following the traumatic event.

For these patients, different scores are used in order to determine the risk, like Glasgow Coma Score $^{2}$, Injury Severity Score ${ }^{3}$, Revised Trauma Score ${ }^{4}$ or the New Trauma Score ${ }^{5}$, the acute physiology and chronic health evaluation $\mathrm{II}^{6}$ or the sequential organ failure assessment? While these scores offer great support for the doctors, in order to standardise the therapeutic approach, the addition of new methods of assessing the risk in patients with multiple traumas, and in particular in those with associated thoracic trauma, can offer valuable information ${ }^{8,9}$.

The objective OF THe Study was to analyze the potential of creatine kinase MB isoenzyme and troponin to be used as paraclinical tests for the initial evaluation of polytrauma patients, with thoracic trau$\mathrm{ma}$, in determining the risk of death within the first 24 hours after admission.

\section{Material AND MEthods}

We studied 33 patients with severe thoracic polytrauma, admitted to the emergency room in the County Clinical Emergency Hospital Constanta, Romania, between 2014-2017.

The inclusion criteria were: age over 16 years, diagnosis of major polytrauma with chest trauma. Patients with unknown mechanisms of trauma have been excluded from the study.

We compared the values of the creatine kinase isoenzyme $\mathrm{MB}(\mathrm{CK}-\mathrm{MB})$ and troponin, on admission, in patients who survived 24 hours after admission and in patients who died during the same period of time.

In order to determine the statistical tests to run (parametric or nonparametric), we assessed the normality of the data by observing the histogram and running the Shapiro-Wilk test. Depending on the results, we ran $\mathrm{T}$ test or Mann-Whitney $\mathrm{U}$ test to compare the values among the two groups of patients. chez les patients n'ayant pas survécu après 24 heures de suivi.

Conclusions. Les valeurs de la troponine semblent être utiles pour identifier les patients présentant un risque accru de décès.

Mots-clés: créatine-kinase MB, troponine, polytrauma, traumatisme thoracique.

After comparing the values, we decided to run a second type of test, in which we transformed the data according to the existing literature, considering the CK-MB cutoff value24 UI/L. For troponin, values less between $0.0 .02 \mathrm{ng} / \mathrm{mL}$ have been considered negative, values between $0.021-0.06 \mathrm{ng} / \mathrm{mL}$ - positive + , values between $0.061-0.22 \mathrm{ng} / \mathrm{mL}$ - positive ${ }^{++}$, and values above $0.22 \mathrm{ng} / \mathrm{mL}$ - positive ${ }^{+++}$. After the transformation, we ran Chi-square test for testing the association between the patients' status after 24 hours and enzymes values.

For all statistical tests, we considered the result as being staitstically significant for $\mathrm{p}$ values less or equal to 0.05 .

\section{Results}

From the study group of 33 patients, 11 died during the first 24 hours, and 22 patients survived. The average age of the survivors group was 48.73 years, with a standard deviation of 14.01 and median value of 50 . For the group of patients who died within 24 hours after admission, the average age was 50.64 years, with a standard deviation of 12.37 and median value of 57 . The difference was not statistically significant $(\mathrm{p}=0.704)$. For both groups, males represented most of the patients, 16 patients $(72.7 \%)$ being males in the survivors group and 9 patients (81.8\%) being males in the group of deceased patients. There is no statistically significant difference, according to gender distribution, between the groups $(\mathrm{p}=0.566)$.

\section{Creatine kinase MB (CK-MB)}

Analysing the CK-MB values, we observed that average values in the case of deceased patients was more than double when compared to patients who survived (248 U/L compared to $106.64 \mathrm{U} / \mathrm{L}$ ), while the median was similar, $60 \mathrm{UI} / \mathrm{L}$ (Table 1).

The Shapiro-Wilk test had statistically significant results, with $\mathrm{p}$ values less than 0.001 for both groups (Table 2). In Figure 1, the distribution of the patients according to CK-MB values is represented. We noted that most of the patients had values less 


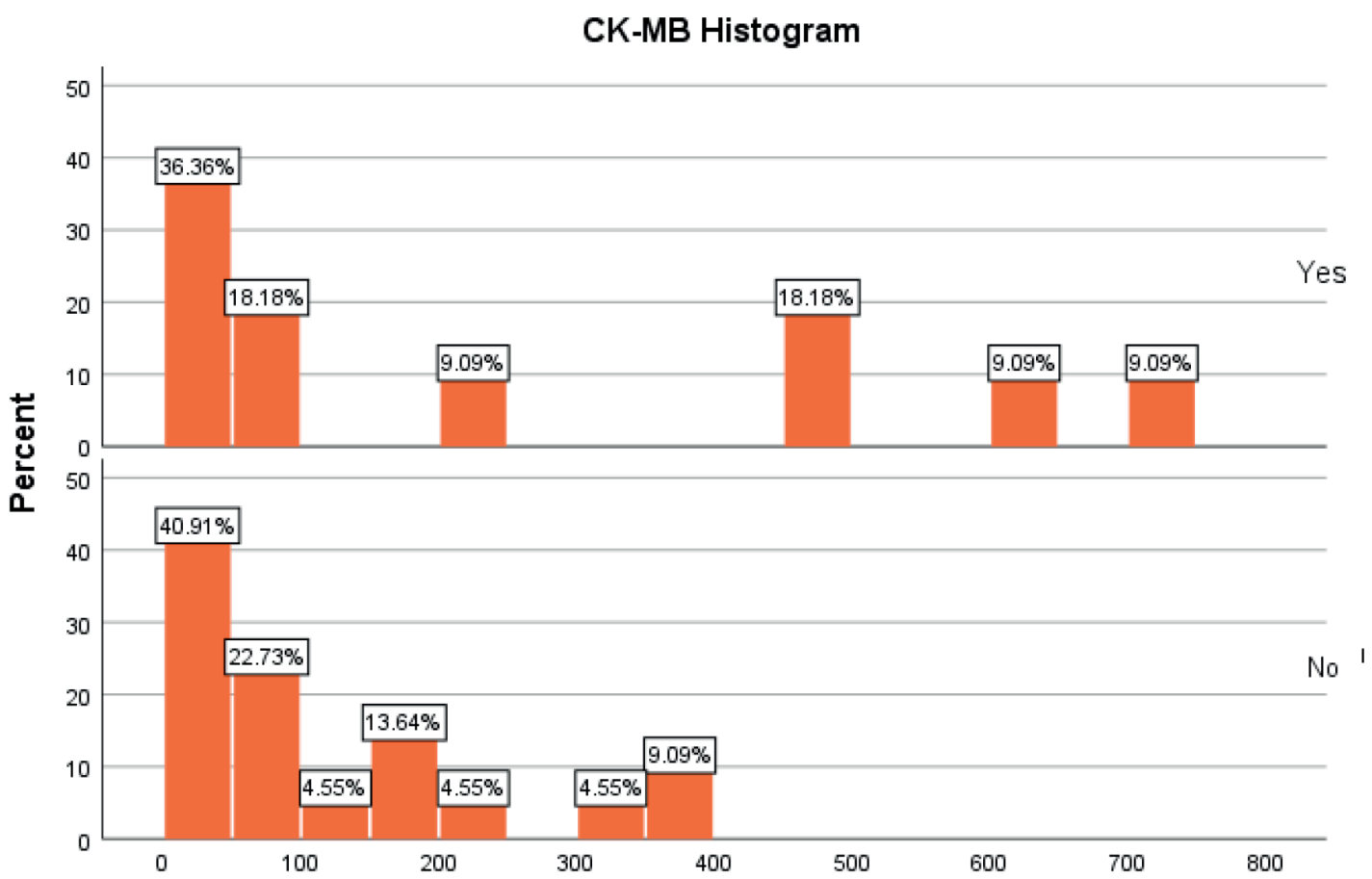

Figure 1. Distribution of CK-MB values on admission depending on evolution.

Table 1. Descriptive statistical analysis of CK-MB between the two groups.

\begin{tabular}{cccc}
\hline & \multicolumn{3}{c}{ Died within 24 hours of admission } \\
\cline { 2 - 4 } & No & Yes & Total \\
\hline $\mathrm{N}$ & 22 & 11 & 33 \\
\hline Mean & 106.64 & 248.00 & 153.76 \\
\hline Standard deviation & 106.844 & 262.204 & 183.182 \\
\hline Median & 60.00 & 60.00 & 33555.752 \\
\hline Variance & 11415.576 & 68751.000 & 1.640 \\
\hline Skewness & 1.392 & .699 & 1.919 \\
\hline Kurtosis & .850 & -1.317 & 19 \\
\hline Minimum & 19 & 20 & 700
\end{tabular}

Table 2. Shapiro-Wilk test for CK-MB.

\begin{tabular}{|c|c|c|c|c|c|c|c|}
\hline \multirow{4}{*}{ CK-MB at admission } & \multirow{2}{*}{$\begin{array}{c}\text { Died within } 24 \text { hours of } \\
\text { admission }\end{array}$} & \multicolumn{3}{|c|}{ Kolmogorov-Smirnov ${ }^{a}$} & \multicolumn{3}{|c|}{ Shapiro-Wilk } \\
\hline & & Statistic & $d f$ & Sig. & Statistic & $d f$ & Sig. \\
\hline & No & .271 & 22 & .000 & .775 & 22 & .000 \\
\hline & Yes & .309 & 11 & .004 & .803 & 11 & .010 \\
\hline
\end{tabular}

than $50 \mathrm{UI} / \mathrm{L}$, summing up to $36 \%$ of the deceased patients and $41 \%$ of the patients in the survivors group. Based on the results of the test and the observation of the histogram, we concluded that the data do not follow a normal distribution, therefore, for comparison, we used nonparametric tests.

Ranks test (Table 3) indicates that the mean range is significantly higher for deceased patients group, with a value of 19.64 , while for the survivors is 15.98. This indicates, once more, that patients who died had higher values of CK-MB compared to the survivors.

The result of the test was not significant $(z=-1 / 101, p=0.268)$ (Table 4)), suggesting that there is no statistically significant difference between the two groups, when comparing the CK-MB values. 
Table 3. CK-MB Ranks.

\begin{tabular}{|c|c|c|c|c|}
\hline & Died within 24 hours of admission & $\mathrm{N}$ & Mean Rank & Sum of Ranks \\
\hline \multirow{3}{*}{ CK-MB on admission } & No & 22 & 15.68 & 345.00 \\
\hline & Yes & 11 & 19.64 & 216.00 \\
\hline & Total & 33 & & \\
\hline
\end{tabular}

Table 4. Mann-Whitney U test for CK-MB.

\begin{tabular}{cc}
\hline & CK-MB on admission \\
\hline Mann-Whitney U & 92.000 \\
\hline Wilcoxon W & 345.000 \\
\hline Z & -1.109 \\
\hline Asymp. Sig. (2-tailed) & .268 \\
\hline Exact Sig. [2*(1-tailed Sig.)] & $.281^{\mathrm{b}}$ \\
\hline
\end{tabular}

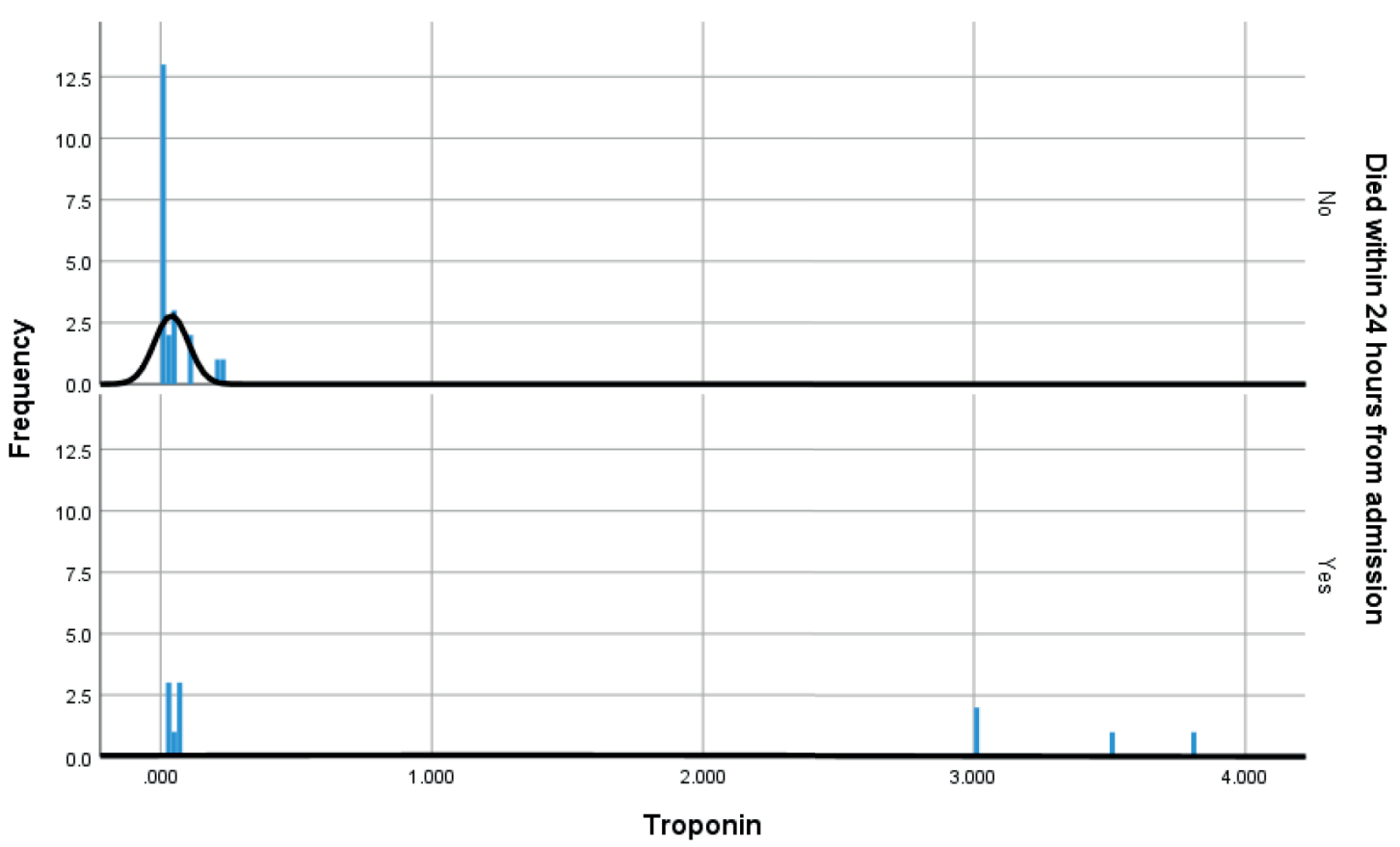

Figure 2. Distribution according to troponin.

\section{Association between CK-MB level on admission and the risk of death}

From the total of 11 patients who died during the first 24 hours after admission, one patient had normal values of CK-MB, while 10 of them had elevated values. At the same time, among the 22 patients that survived after the first 24 hours, 3 had normal values and 19 elevated values. Thus, the percentages of patients with normal values were $13.6 \%$ in the survivors group and $9.1 \%$ in the deceased group (Table 5).

By running the Chi-Square test, the result is not statistically sgnificant $(p=0.7)$, indicating the lack of association between CK-MB category and risk of death.

\section{Troponin}

For troponin, the mean values in deceased patients were $1.24 \mathrm{ng} / \mathrm{mL}$, with a standard deviation of $1.66 \mathrm{ng} / \mathrm{mL}$. In patients who survived, the mean values for troponin were $0.039 \mathrm{ng} / \mathrm{mL}$, with a standard deviation of $0.063 \mathrm{ng} / \mathrm{mL}$. Median values are significantly different, with $0.012 \mathrm{ng} / \mathrm{mL}$ in surviving patients and $0.73 \mathrm{ng} / \mathrm{mL}$ in deceased patients (Table 6).

According to the result of Shapiro-Wilk test (Table 7) and the histogram (Figure 2), the distribution of troponin values differs, statistically significant $(\mathrm{p}<0.001)$, and graphical way from a normal distribution. Therefore, for comparing the values, we used the nonparametric test Mann-Whitney U. 
Table 5. Patients' evolution and CK-MB category crosstabulation

\begin{tabular}{|c|c|c|c|c|c|}
\hline & & & \multicolumn{3}{|c|}{ Died within 24 hours of admission } \\
\hline & & & No & Yes & Total \\
\hline \multirow{4}{*}{ CK-MB category } & \multirow{2}{*}{ Normal } & Counts & 3 & 1 & 4 \\
\hline & & $\%$ din Died within 24 hours of admission & $13.6 \%$ & $9.1 \%$ & $12.1 \%$ \\
\hline & \multirow{2}{*}{ Elevated } & Counts & 19 & 10 & 29 \\
\hline & & $\%$ din Died within 24 hours of admission & $86.4 \%$ & $90.9 \%$ & $87.9 \%$ \\
\hline \multirow{2}{*}{ Total } & & Counts & 22 & 11 & 33 \\
\hline & & $\%$ din Died within 24 hours of admission & $100.0 \%$ & $100.0 \%$ & $100.0 \%$ \\
\hline
\end{tabular}

Table 6. Descriptive statistics for troponin.

\begin{tabular}{cccc}
\hline & \multicolumn{3}{c}{ Died within 24 hours of admission } \\
\cline { 2 - 4 } & Yes & No & Total \\
\hline $\mathrm{N}$ & 22 & 11 & 33 \\
\hline Mean & .03955 & 1.24055 & .43988 \\
\hline Standard Deviation & .062872 & 1.666787 & .03000 \\
\hline Median & .01200 & .07300 & 1.201 \\
\hline Variance & .004 & 2.778 & 2.482 \\
\hline Skewness & 2.109 & .722 & 4.583 \\
\hline Kurtosis & 3.750 & -1.738 & .000 \\
\hline Minimum & .000 & .020 & 3.800 \\
\hline Maximum & .220 & 3.800 & \\
\hline
\end{tabular}

Table 7. Shapiro-Wilk test for troponin.

\begin{tabular}{cccccccc}
\hline & \multirow{2}{*}{$\begin{array}{c}\text { Died within 24 hours } \\
\text { of admission }\end{array}$} & \multicolumn{3}{c}{ Kolmogorov-Smirnov $^{a}$} & \multicolumn{3}{c}{ Shapiro-Wilk } \\
\cline { 2 - 7 } Troponin on admission & No & Statistic & $d f$ & Sig. & Statistic & $d f$ & Sig. \\
\cline { 2 - 8 } & Yes & .315 & 22 & .000 & .658 & 22 & .000 \\
\cline { 2 - 8 } & & .395 & 11 & .000 & .685 & 11 & .000 \\
\hline
\end{tabular}

Table 8. Troponin ranks

\begin{tabular}{cccc}
\hline \multirow{3}{*}{ Troponin on admission } & $\begin{array}{c}\text { Died within 24 hours } \\
\text { of admission }\end{array}$ & N & Mean Rank \\
\cline { 2 - 4 } & No & 22 & 13.30 \\
\cline { 2 - 4 } & Yes & 11 & 24.41 \\
\hline
\end{tabular}

Graphically, we noticed that in the case of deceased patients, none of them have troponin values less than $0.02 \mathrm{ng} / \mathrm{mL}$, while in the case of the patients who survived the first 24 hours, almost $60 \%$ of them have values less than $0.02 \mathrm{ng} / \mathrm{mL}$. Also, in the case of the deceased patients, $36.37 \%$ had values higher than $3 \mathrm{ng} / \mathrm{mL}$.

Comparing the ranks, the average rank in the deceased patients group was 24,41, significantly higher when compared to the survivors group, for which the average rank was 13.3 (Table 8).

The observed difference was statistically significant $(z=-3.126, p=0.002)$ (Table 9). This sustains, with a high degree of confidence, that patients who survived the first 24 hours after admission had significantly lower values of troponin.

\section{Risk of death related to troponin values}

For estimating the association between troponin values and the risk of death, we crosstabulated the data. The results (Table 10) show that in the group of patients who died within 24 hours from admission, all of them were in the category positive ++ ( 4 patients $)$ or positive +++ ( 7 patients). In the group of survivors, from the total of 22 patients, 6 were considered to be negative, 7 positive,+ 5 positive ${ }^{++}$and 4 positive ${ }^{+++}$. 
Table 9. Mann Whitney-U test for troponin depending on patients' evolution.

\begin{tabular}{cc}
\hline & Troponin on admission \\
\hline Mann-Whitney U & 39.500 \\
\hline Wilcoxon W & 292.500 \\
\hline Z & -3.126 \\
\hline Asymp. Sig. (2-tailed) & .002 \\
\hline Exact Sig. [2*(1-tailed Sig.)] & $.001^{\mathrm{b}}$ \\
\hline
\end{tabular}

Table 10. Patients' evolution and troponin category crosstabulation

\begin{tabular}{|c|c|c|c|c|c|}
\hline & & & \multicolumn{3}{|c|}{ Died within 24 hours of admission } \\
\hline & & & No & Yes & Total \\
\hline \multirow{8}{*}{$\begin{array}{l}\text { Troponin } \\
\text { category }\end{array}$} & \multirow{2}{*}{ Negativ } & Counts & 6 & 0 & 6 \\
\hline & & $\%$ from Died within 24 hours of admission & $27.3 \%$ & $0.0 \%$ & $18.2 \%$ \\
\hline & \multirow{2}{*}{ Positive +} & Counts & 7 & 0 & 7 \\
\hline & & $\%$ from Died within 24 hours of admission & $31.8 \%$ & $0.0 \%$ & $21.2 \%$ \\
\hline & \multirow{2}{*}{ Positive ++} & Counts & 5 & 4 & 9 \\
\hline & & $\%$ from Died within 24 hours of admission & $22.7 \%$ & $36.4 \%$ & $27.3 \%$ \\
\hline & \multirow{2}{*}{ Positive +++} & Counts & 4 & 7 & 11 \\
\hline & & $\%$ from Died within 24 hours of admission & $18.2 \%$ & $63.6 \%$ & $33.3 \%$ \\
\hline \multirow{2}{*}{\multicolumn{2}{|c|}{ Total }} & Counts & 22 & 11 & 33 \\
\hline & & $\%$ from Died within 24 hours of admission & $100.0 \%$ & $100.0 \%$ & $100.0 \%$ \\
\hline
\end{tabular}

Table 11. Chi-square test for troponin.

\begin{tabular}{cccc}
\hline & Value & df & Asymptotic Significance (2-sided) \\
\hline Pearson Chi-Square & $11.545^{\text {a }}$ & 3 & .009 \\
\hline Likelihood Ratio & 15.224 & 3 & .002 \\
\hline $\mathrm{N}$ of Valid Cases & 33 & & \\
\hline a. ${ }^{a} 6$ cells $(75.0 \%)$ have expected count less than 5. The minimum expected count is 2.00. \\
\hline
\end{tabular}

The graphical representation of the proportion (Figure 3) offers a better insight on the distribution of patients, based on troponin category.

When applying the chi-square test, the percentage of cells with expected values less than 5 is higher than 20\%, therefore, we considered the statistical significance obtained from the Likelihood Ratio, which is 0.002 . This result indicates a significant association between troponin category and risk of death, thus, positioning a patient into positive ++ or positive +++ indicates a significantly higher risk of death in the first 24 hours after admission.

\section{Discussion}

In the case of CK-MB, we observed that almost $90 \%$ of all the patients had increased values. Combined with the fact that the percentage of patients with elevated values was almost identical in both groups ( $86.4 \%$ vs $90.9 \%$ ), we can conclude that CK-MB is not helpful in identifying the risk of death in patients with polytrauma and associated thoracic trauma. Other studies concluded that CK-MB is not useful in determining the cardiac injury, as it is not specific enough $^{10-12}$.

In the case of troponin, it proved to increase more in patients who didn't survive in the first 24 hours after admission. There are a number of studies that proved the fact that trauma patients with increased troponin values are of greater risk of death ${ }^{13,14}$.

As a limitation of the study, we didn't try to identify subsequent organ (cardiac) involvement, as we considered only the main outcome, death within 24 hours from admission being the only objective of this study.

\section{Conclusions}

Increased values of creatine kinase $\mathrm{MB}$ are not associated with higher risk of death, while troponin values may be useful during initial assessment of polytrauma patients with thoracic trauma, in order to identify the patients with increased risk of death. 


\section{Patients distribution according to troponin category and survival at $\mathbf{2 4}$ hours after admission}

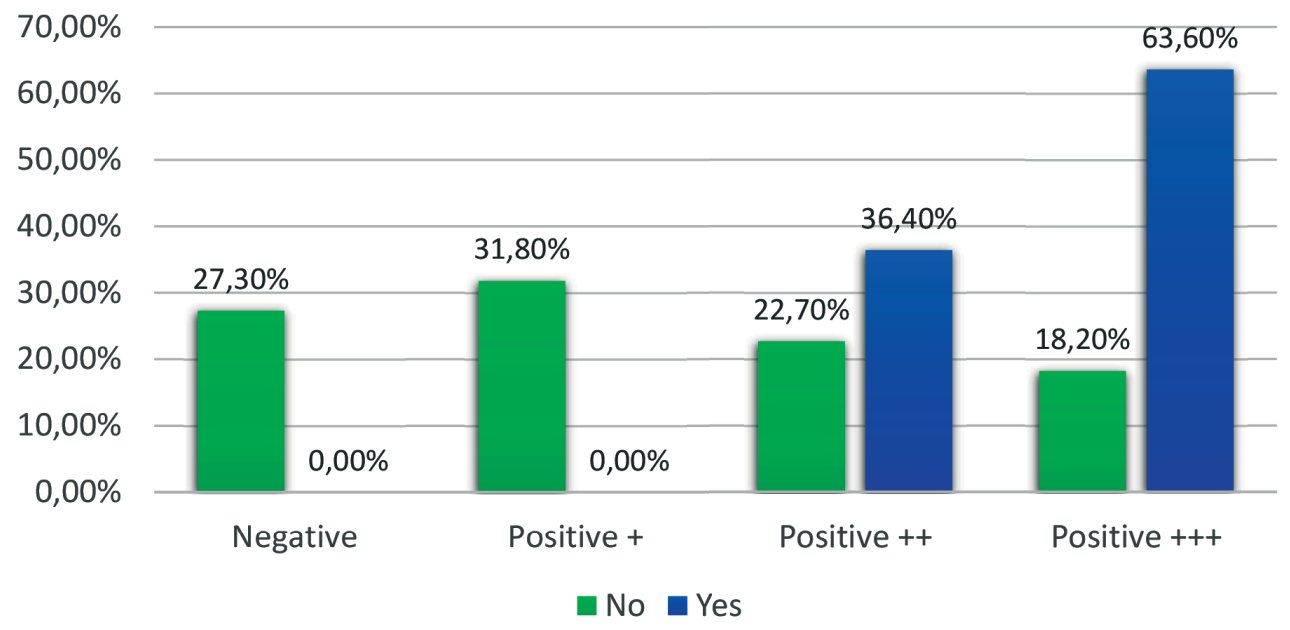

Figure 3. Patients distribution according to troponin category and survival at 24 hours after admission

\section{Compliance with Ethics Requirements:}

„The authors declare no conflict of interest regarding this article"

„The authors declare that all the procedures and experiments of this study respect the ethical standards in the Helsinki Declaration of 1975, as revised in 2008(5), as well as the national law. Informed consent was obtained from all the patients included in the study"

"No funding for this study"

\section{References}

1. World Health Organization. Global burden of disease. Geneva: WHO Press; 2015.

2. Teasdale G, Jennett B. Assessment of coma and impaired consciousness. A practical scale. Lancet 1974;2(7872):81-4.

3. Baker SP, O'Neill B, Haddon W, Jr., Long WB. The injury severity score: a method for describing patients with multiple injuries and evaluating emergency care. J Trauma 1974;14(3):187-96.

4. Champion HR, Sacco WJ, Copes WS, Gann DS, Gennarelli TA, Flanagan ME. A revision of the Trauma Score. J Trauma1989;29(5):623-9.

5. Jeong JH, Park YJ, Kim DH, et al. The new trauma score (NTS): a modification of the revised trauma score for better trauma mortality prediction. BMC Surgery 2017;17(1):77.
6. Knaus WA, Draper EA, Wagner DP, Zimmerman JE. APACHE II: a severity of disease classification system. Critical Care Medicine 1985;13(10):818-29.

7. Vincent JL, de Mendonca A, Cantraine F, et al. Use of the SOFA score to assess the incidence of organ dysfunction/ failure in intensive care units: results of a multicenter, prospective study. Working group on "sepsis-related problems" of the European Society of Intensive Care Medicine. Critical Care Medicine 1998;26(11):1793-800.

8. Bodean $\mathrm{O}$, Bratu $\mathrm{O}$, Munteanu $\mathrm{O}$, et al. Iatrogenic injury of the low urinary tract in women undergoing pelvic surgical interventions. Arch Balk Med Union 2018;53(2):281-284.

9. Draghici T, Negreanu L, Bratu OG, et al. Liver abnormalities in patients with heart failure. Arch Balk Med Union 2018;53(1):76-81.

10. Bansal MK, Maraj S, Chewaproug D, Amanullah A. Myocardial contusion injury: redefining the diagnostic algorithm. Emergency Medicine Journal 2005;22(7):465-9.

11. Diaconu C, Bartos D. Biomarkers: a step forward in heart failure diagnosis and risk stratification. Medicina Internă 2012;IX(1):35-39.

12. Horodinschi R, Ionescu C, Belciu D, Diaconu C. How can anemia affect the heart? Arch Balk Med Union 2017;52(2):214-218.

13. Mahmood I, El-Menyar A, Dabdoob W, et al. Troponin T in patients with traumatic chest injuries with and without cardiac involvement: Insights from an observational study. North American Journal of Medical Sciences 2016;8(1):17-24.

14. Lippi G, Buonocore R, Mitaritonno M, Cervellin G. Cardiac troponin $I$ is increased in patients with polytrauma and chest or head trauma. Results of a retrospective case-control study. J Med Biochem 2016;35(3):275-281. 